\title{
DISCUSSION
}

\section{A new model of vane shear strength testing in soils}

\author{
P. H. MORRIS and D. J. WILliAMS (1993). Géotechnique 43, No. 3, 489-500
}

\section{U. Gori, Institute of Applied Geology, Urbino University, Italy}

The Authors' empirical factor $\mu_{\mathrm{v}}$ is one of the most controversial aspects of the problem, because of differences between in situ and laboratory measured undrained cohesion and shear strength mobilized by stability analyses.

For the past 20 years many researchers have proposed various corrective factors for the vane shear test, sometimes with scattered results which should be treated with care because the data are not universally applicable (Ladd, 1973; Schmertmann, 1975; Lunne, Eide \& De Ruiter, 1977; Kirkpatrick \& Khan, 1981; Leroueil \& Jamiolkowski, 1991; Mesri, 1993).

For the Leda and Osaka clays, the $\mu_{\mathrm{v}}$ values given in the Paper do not permit any comparison or interpretation and thus their inclusion in Fig. 11 could be of dubious meaning. The Leda samples are sensitive silty marine clay sediments but the Osaka samples are taken from reconstituted alluvial marine clays. In other words, with remoulding, the Osaka clays have lost their natural structural anisotropy and the original cohesive peak value, and so the $\mu_{\mathrm{V}}$ can be related only to the fabric arrangements connected with the consolidation effects and not with ageing or the slight decrease with overconsolidation increase. From equations (19), (22) and (23), values of $s_{\mathrm{v}} / \sigma_{\mathrm{vc}}{ }^{\prime}$ are too variable: for Leda clays they are, respectively, $0.43,0.44,0.39$ and 0.52 for tests L1, L2, L3 and L4 in Table 2. For the Osaka clays $s_{\mathrm{v}} / \sigma_{\mathrm{vc}}{ }^{\prime}$ is $0.49,0.36$ and 0.33 for tests $\mathrm{O} 1, \mathrm{O} 2$ and $\mathrm{O} 3$ in Table 3. Such results do not agree with the average data in the literature. The $\mu_{\mathrm{v}}$ corrective factor plotted in Fig. 11 varies from about 0.8 to 1.2 for Leda clays and from about 0.72 to 0.82 for Osaka clays. However, using equation (19) $s_{\mathrm{v}} / \sigma_{\mathrm{vc}}{ }^{\prime}$ varies from 0.88 to 1.18 and, surprisingly, from 0.57 to 0.72 for Leda and Osaka clays, respectively.

A problem not discussed in the Paper concerns the effect produced by the consolidation on both the edge and the central part of the clay samples. This is especially significant for the Osaka clays, where $\sigma_{\mathrm{h}}{ }^{\prime} / \sigma_{\mathrm{v}}{ }^{\prime}$ ranges between 0.45 and 0.48 .

The dimensions of the adopted consolidation cells of both Leda and Osaka clays are sensibly different. The degree of local drainage in the shear zone is related strictly to the sample sizes and test conditions (Atkinson \& Richardson, 1987).

The ratios between the diameters of the utilized blades and the diameters of the consolidation cells vary between 0.27 for Leda clays and 0.5 , 0.25 and 0.16 for Osaka clays. If the ratio increases, the differences in consolidation, permeability and water content between the edges of the cell and the vertical surface of the shear cylinder decrease. Otherwise the value of horizontal torque will be still more affected by increments in the ratio. Nevertheless the relative proportions of the torque $T_{\mathrm{h}} / T_{\mathrm{v}}$ appear small: they range between 0.06 for London clays and 0.16 in conventional interpretations (Wroth, 1984).

In the same way, for low ratios of blade diameter to cell diameter, the variable consolidation between the centre and the edge of the cell can be considered not to influence determination of the vertical or horizontal torque. Such observations appear fundamental in the laboratory experiments where the dimension of the cells are small and have a significant effect on the ratio of blade diameter to cell diameter.

Secondary compression affected the time to failure in relation to the undrained laboratory shear strength. As the coefficient $\alpha$ represents the ratio between compressibility with respect to time $C_{\alpha}$ and compressibility with respect to the effective stress $C_{\mathrm{c}}$ (Mesri, 1987), it is easy to understand that in the range of $\alpha=0.02-0.08$ (related to plasticity and organic matter) if $C_{\mathrm{c}}$ decreases with pressure, $C_{\alpha}$ also decreases with time. Consequently the rotation of the vane $\left(5^{\circ} / \mathrm{min}\right.$ and $6 \%$ min for Leda and Osaka clays respectively) could be allowed for in all cases. In addition, the volumetric straining as a result of the local drainage of the slip plane influences the cohesive undrained value in relation to the overconsolidation ratio and various rates of loading.

A $\mu_{\mathrm{RL}}$ correction factor (Mesri, 1989, 1993) was proposed for considering the time effect and the mode of shear. According to the sphere of influence concept (Blight, 1968) it is appropriate for silty Osaka clays because of their ability on the failure surfaces to drain partially; to achieve a degree of consolidation $U$ which is much less 
Table 4

\begin{tabular}{|c|c|c|c|c|c|c|c|c|}
\hline Samples & $\begin{array}{l}\sigma_{\mathbf{v}}{ }^{\prime} \\
\mathrm{kPa}\end{array}$ & $\underset{\%}{W_{\mathbf{n}}}:$ & $\begin{array}{c}C_{\mathrm{v}}: \\
\mathrm{mm}^{2} / \mathrm{s}\end{array}$ & $\begin{array}{l}t_{50}: \\
\text { min }\end{array}$ & $\begin{array}{l}\Delta H: \\
\mathrm{mm}\end{array}$ & $\alpha_{\max }$ & $\begin{array}{c}t_{\mathrm{r}}: \\
\mathrm{s}\end{array}$ & $T$ \\
\hline Caotic clays & 100 & 61 & $33 \times 10^{-5}$ & 100 & 1.50 & $39^{\circ}$ & 12 & $40 \times 10^{-4}$ \\
\hline Colombacci clays & 100 & 43 & $45 \times 10^{-4}$ & 8 & 1.65 & $70^{\circ}$ & 21 & $95 \times 10^{-3}$ \\
\hline Pliocene clays & 100 & 34 & $33 \times 10^{-4}$ & 10 & $1 \cdot 30$ & $70^{\circ}$ & 21 & $69 \times 10^{-3}$ \\
\hline
\end{tabular}

than $10 \%$ versus the time factor $T$ (taken as $\leq 0.05$ ), the rate adopted should be higher than the rate used in the laboratory test referred to.

For different silty clays of remoulded formation, one-dimensionally consolidated in cells of 40 $\mathrm{mm}$ diameter, at a rate of $200^{\circ} / \mathrm{min}$ in the laboratory vane test $(D=10 \mathrm{~mm}$ and $H=15.5 \mathrm{~mm})$ the data shown in Table 4 have been obtained (Gori, 1994). $t_{\mathrm{r}}$ is the rupture time during the test and $\alpha^{\prime}$ is the angular deformation value of the vane spring.

I would suggest that many discrepancies between laboratory, field and back-calculated undrained cohesion data (Azzouz, Baligh \& Ladd, 1983; Aas, Lacasse, Lunne \& Hoeg, 1986) and the mineralogical, chemical-physical and microstructural behaviour of the soils tested

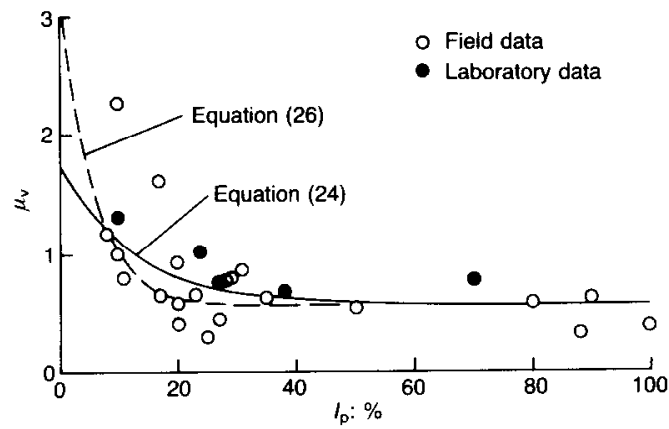

(a)

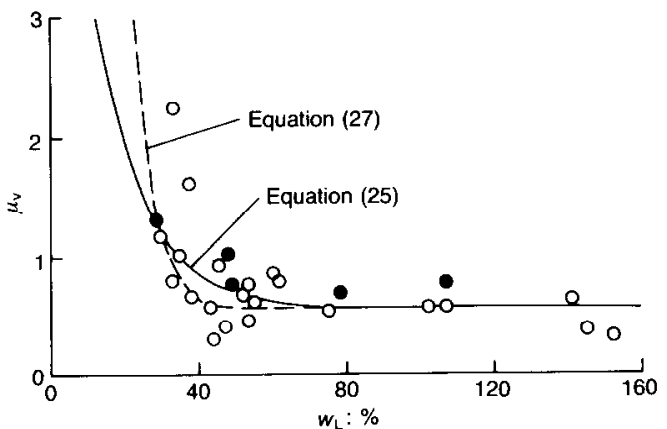

(b)

Fig. 12. Variation of correction factor $\mu_{v}$ with: (a) plasticity index; (b) liquid limit (adapted from Morris \& Williams, 1994) should be investigated. Two clays with similar plastic index can have very different geotechnical behaviour. Consequently the usual interrelationships between the empirical corrective vane factors and the plastic index do not provide a satisfactory practical approach.

\section{Authors' reply}

The correction factor $\mu_{\mathrm{V}}$ is not intended to replace Bjerrum's (1973) correction factor or any other correction factor which relates vane shear strength to shear strength obtained from backanalysis of full-scale field failures. It has been introduced only to compensate for the failure of the new theoretical model to address directly some pore pressure and shearing rate phenomena that occur in vane shear tests.

We consider that statistical methods (Figs 9 and 10) are more appropriate for the calculation of $\mu_{\mathrm{v}}$ values and their probable errors (Fig. 11) using laboratory data than the point by point method used by Professor Gori. The $\mu_{\mathrm{v}}$ values presented lead to $s_{\mathrm{v}} / \sigma_{\mathrm{v}}{ }^{\prime}$ ratios of 0-46 for the Leda clay and 0.33-0.36 for the Osaka clays. (Simple statistical methods are normally used to obtain $s_{\mathrm{v}} / \sigma_{\mathrm{v}}{ }^{\prime}$ ratios from field data.) The $s_{\mathrm{v}} / \sigma_{\mathrm{v}}{ }^{\prime}$ ratios calculated by either method are easily encompassed within the ranges $0 \cdot 09-0.63$ and $0.14-0.24$ for field and laboratory data, respectively, from 34 clays with a worldwide distribution listed by Morris \& Williams (1994).

If the present form of the theoretical model is to be of practical use, $\mu_{\mathrm{v}}$ must be evaluated. Professor Gori's assertion that an empirical correlation of $\mu_{\mathrm{v}}$ with $I_{\mathrm{p}}$ cannot provide a satisfactory practical approach is unduly pessimistic. Plots of $\mu_{\mathrm{v}}$ versus $I_{\mathrm{p}}$ and liquid limit $w_{\mathrm{L}}$ based on field and laboratory data from 28 clays with a worldwide distribution are shown in Fig. 12. The regression lines for all data points are given by (Morris \& Williams, 1994)

$$
\begin{aligned}
& \mu_{\mathrm{V}}=1.18 \exp \left(-0.08 I_{\mathrm{p}}\right)+0.57 \\
& \mu_{\mathrm{v}}=7.01 \exp \left(-0.08 w_{\mathrm{L}}\right)+0.57
\end{aligned}
$$

Both $\mu_{\mathrm{v}}$ correlations are quite strong, with levels of significance of less than 0.01 . However, the scatter of the $I_{\mathrm{p}}$ data points is greater than that of the equivalent data points for Bjerrum's correc- 
tion factor (Ladd, 1975; Dascal \& Tournier, 1975; Morris \& Williams, 1994). Case-specific $\mu_{\mathrm{v}}$ values should be used whenever possible.

The laboratory data points all plot reasonably close to the regression lines but are biased to the high side. This may reflect the different sizes of typical field and laboratory vane. However, a bias to the low side would be expected if consolidation rate were the dominant factor.

If the laboratory data are considered to be incompatible with the field data and are therefore excluded from the data set, the $\mu_{\mathrm{v}}$ correlations remain strong, with levels of significance of approximately $0 \cdot 01$. The regression lines become (Fig. 12)

$$
\begin{aligned}
& \mu_{\mathrm{v}}=2.63 \exp \left(-0.18 I_{\mathrm{p}}\right)+0.57 \\
& \mu_{\mathrm{v}}=138 \exp \left(-0.18 w_{\mathrm{L}}\right)+0.57
\end{aligned}
$$

These regression lines differ significantly from those for all data points. However, except at low values of $I_{\mathrm{p}}$ and $w_{\mathrm{L}}$, the difference is small compared with the scatter of the data points.

The Authors concur with Professor Gori's views on the importance of further research into the effects on the vane shear strength of soils of shearing rate, consolidation, and soil mineralogy and microstructure.

\section{REFERENCES}

Aas, G., Lacasse, S., Lunne, T. \& Hoeg, K. (1986). Use of in situ tests for foundation design on clay. Proceedings of conference on the use of in situ tests in geotechnical engineering, Blacksburg, pp. 1-30. New York: American Society of Civil Engineers.

Atkinson, J. H. \& Richardson, D. (1987). The effect of local drainage in shear zones on the undrained strength of overconsolidated clay. Géotechnique 37, Sept., 393-403.

Azzouz, A. S., Baligh, M. M. \& Ladd, C. C. (1983). Corrected field vane strength for embankment design. $I$. Geotech. Engng Proc. Am. Soc. Civ. Engrs 101, 730734.
Bjerrum, L. (1973). Problems of soil mechanics and construction on soft clays and structurally unstable soils (collapsible, expansive and others). Proc. 8th Int. Conf. Soil Mech., Moscow 3, 111-159.

Blight, G. E. (1968). A note on field vane testing of silty soils. Can. Geotech. J. 5, 142-149.

Dascal, O. \& Tournier, J. P. (1975). Embankments on soft and sensitive clay foundations. Proc. Am. Soc. Civ. Engrs 101, GT3, 297-314.

Gori, U. (1994). The time effect on the undrained cohesion recovery in clayey soils, using the vane test. Proc. 7th Congr. IAEG, Lisbon, in press.

Kirkpatrick, W. M. \& Khan, A. J. (1981). Interpretation of vane test. Proc. I0th Int. Conf. Soil Mech. 2, 501506.

Ladd, C. C. (1973). Discussion on State of the art report, by L. Bjerrum. Proc. 8th Int. Conf. Soil Mech., Moscow 4.2, 435-464.

Ladd, C. C. (1975). Discussion on Measurement of in situ shear strength. Proceedings of conference on in situ measurements of soil properties, vol. 2, pp. 153160. New York: American Society of Civil Engineers.

Leroueil, S. \& Jamiolkowski, M. (1991). Exploration of soft soil and determination of design parameters. General report, Session 1. Geo-Coast '91, Yokohama.

Lunne, T., Eide, O. \& De Ruiter, J. (1977). Correlations between cone resistance and vane shear strength in some Scandinavian soft to medium stiff clays. Norw. Geotech. Inst. Publn, No. 116, 1-12.

Mesri, G. (1987). The fourth law of soil mechanics: the law of compressibility. Proc. Int. Symp. Geotech. Engng Soft Ground, Mexico 2, 179-187.

Mesri, G. (1989). A re-evaluation of $S_{u}(\mathrm{mob})=0 \cdot 22 \sigma^{\prime} p$ using laboratory shear tests. Can. Geotech. J. 26, No. $1,162-164$

Mesri, G. (1993). Discussion on Initial investigation of the soft clay test site at Bothkennar, by D. F. T. Nash, J. J. M. Powell \& I. M. Lloyd. Géotechnique 43, Sept., 503-504.

Morris, P. H. \& Williams, D. J. (1994). Effective stress vane shear strength correction factor correlations. Can. Geotech. J. 31, in press.

Schmertmann, J. H. (1975). Measurement of in situ shear strength. Proceedings of conference on in situ measurements of soil properties, vol. 2, pp. 57-138. New York: American Society of Civil Engineers.

Wroth, C. P. (1984). The interpretation of in situ soil tests. Géotechnique 34, Dec., 449-489. 